\title{
Processing and Proliferative Effects of Human Progastrin in Transgenic Mice
}

\author{
Timothy C. Wang, ${ }^{\star}$ Theodore J. Koh, ${ }^{*}$ Andrea Varro, ${ }^{\ddagger}$ Rachel J. Cahill, ${ }^{\S}$ Charles A. Dangler, ${ }^{\S}$ James G. Fox, \\ and Graham J. Dockray ${ }^{\ddagger}$ \\ *Gastrointestinal Unit, Department of Medicine, Massachusetts General Hospital, Boston, Massachusetts 02114; ${ }^{\ddagger}$ Physiological \\ Laboratory, University of Liverpool, Liverpool, L69 3BX United Kingdom; and ${ }^{\S}$ Division of Comparative Medicine, Massachusetts \\ Institute of Technology, Cambridge, Massachusetts 02139
}

\begin{abstract}
Incompletely processed gastrins have been postulated to play a role in growth of the gastrointestinal tract, but few studies have examined the effects of progastrin on mucosal proliferation in vivo. Human gastrin gene expression and progastrin processing were therefore studied in transgenic mice containing a human gastrin (hGAS) minigene, and compared to processing in mice bearing an insulin gastrin (INS-GAS) transgene that overexpresses amidated gastrin. Progastrin processing was studied using region-specific antisera and radioimmunoassays, biosynthetic labeling, immunoprecipitation, and HPLC. Proliferative effects due to overexpression of processed and unprocessed gastrin in INS-GAS and hGAS mice, respectively, were determined using routine histology and BrdU incorporation. The pancreatic islets of INS-GAS mice were able to produce carboxyamidated G-17, resulting in a twofold elevation of serum amidated gastrin, marked thickening of the oxyntic mucosa, and an increased BrdU labeling index (LI) of the gastric body. In contrast, livers of adult hGAS mice expressed abundant human gastrin mRNA and human progastrin but were unable to process this peptide to the mature amidated form, resulting in markedly elevated serum progastrin levels and normal amidated gastrin levels. Nevertheless, there was a marked increase in the BrdU labeling index of the colon in hGAS mice (LI 7.46 $\pm 1.90 \%$ ), as well as in INS-GAS mice (LI $6.16 \pm 1.17 \%$ ), compared to agematched, wild type control mice (LI 4.01 $\pm 0.98 \%, P<0.05)$. These studies suggest that incompletely processed gastrin precursors may contribute to colonic mucosal proliferation in vivo. (J. Clin. Invest. 1996. 98:1918-1929.) Key words: gastrin gene expression - transgenic mice - progastrin processing • growth factor $\bullet$ colon cancer
\end{abstract}

\section{Introduction}

Gastrin is a peptide hormone with well-characterized properties as an acid secretogogue, but also exerts growth effects on normal and malignant gastrointestinal tissues. The gastrin

Address correspondence to Dr. Timothy C. Wang, Massachusetts General Hospital, G.I. Unit, GRJ 724, 32 Fruit Street, Boston, MA 02114. Phone: 617-726-9228; FAX: 617-726-3673; E-mail: wang@he lix.mgh.harvard.edu

Received for publication 6 June 1996 and accepted in revised form 9 August 1996.

J. Clin. Invest.

(C) The American Society for Clinical Investigation, Inc. 0021-9738/96/10/1918/12 \$2.00

Volume 98, Number 8, October 1996, 1918-1929 gene undergoes significant changes in its tissue specific expression during development. In the adult mammal, gastrin is expressed mainly in the antal $G$ cells of the stomach where it controls acid secretion and stimulates mucosal proliferation (1, 2). In the fetus, gastrin is transiently expressed in developing pancreatic islets during a critical period of islet cell differentiation $(3,4)$. The pancreatic expression of gastrin promptly ceases after birth along with islet neogenesis, suggesting that gastrin may be a regulatory factor in the development of islet precursor cells (5). Transgenic studies have confirmed that gastrin in combination with TGF $\alpha$ can function as a growth factor for the pancreatic islets (6).

Because gastrin transcripts in the pancreas and stomach initiate from the same start site, differential transcriptional regulation is achieved by nuclear factors that interact with the same promoter (5). Studies based on transient transfections of human gastrin promoter constructs in cultured rat islet cell lines identified an islet-cell-specific enhancer (7-9). This enhancer sequence in the human gastrin promoter was located within $200 \mathrm{bp}$ of the transcriptional initiation site. However, the results obtained by DNA transfection into differentiated cells in culture do not always correlate precisely with results obtained in the whole animal. Thus, transgenic animals provide an essential tool for identifying all of the cis-regulatory sequences required for implementation of the complete program of gene expression during development.

In addition, gastrin may also be regulated at the level of prohormone processing. Gastrin, like other small peptides, is made initially as a larger precursor molecule, preprogastrin, which is rapidly converted to progastrin by cleavage of an $\mathrm{NH}_{2}$-terminal signal peptide at residues 21 and 22 (10). The major steps involved in conversion of progastrin to its active product include endopeptidase cleavage, carboxypeptidase E trimming of the $\mathrm{COOH}$-terminal basic residues, and conversion of Gly-extended intermediates to yield amidated products $(11,12)$. The processing of human gastrin has been studied in a limited number of transformed cell lines (13-17), but expression and processing of human gastrin gene constructs has not been studied extensively in vivo.

Few studies have looked at the effect of overexpression of unprocessed forms of human gastrin. Amidated gastrin is believed to be the main biologically active form, but recent studies have raised the possibility that nonamidated precursor forms of gastrin, including glycine extended gastrin $(18,19)$ and possibly progastrin (20), may also have growth factor properties. In humans, normally less than $5 \%$ of secreted gastrin peptides are nonamidated precursors, and most of these precursor forms are glycine-extended gastrins (21). However, several cell types in a pathological state are known to demonstrate significant alterations in the processing of gastrin. Increased gastrin synthesis, such as that which occurs in achlorhydria or in response to omeprazole treatment, results in the 
release by $\mathrm{G}$ cells of more unprocessed and incompletedly processed nonamidated progastrin products $(22,23)$. The percentage of nonamidated gastrins was reportedly significantly higher in a number of human neoplastic tissues, such as gastrinomas (24). Finally, human colon cancers and colon cancer cell lines have been shown to express progastrin $(25,26)$, and a possible autocrine growth factor role has been suggested $(27,28)$.

Therefore, to determine whether the known cis-acting elements in the gastrin promoter are sufficient to achieve fetal islet expression, and to study the expression and processing of human progastrin in vivo, we developed transgenic mice containing a human gastrin minigene. The unexpected expression of the human gastrin transgene in adult liver allowed us to compare the processing of progastrin in a nonendocrine organ (liver) to that in an endocrine organ (pancreas) in another transgenic line (INS-GAS) that has been previously reported (6). Finally, the growth factor effects of progastrin expression in the hGAS mice were compared to the effects of amidatedgastrin expression in the INS-GAS mice. These studies support the concept that incompletely processed forms of gastrin can stimulate growth of the gastrointestinal mucosa.

\section{Methods}

Plasmid constructions. The human gastrin gene is encoded in three exons, with the first exon containing untranslated, noncoding sequence $(29,30)$. For this study a 4-kb BamHI-EcoRI human genomic fragment (containing a portion of the first intron, all of exons 2 and 3 containing the gastrin coding sequences, all of the second intron and $1.5 \mathrm{~kb}$ of $3^{\prime}$ flanking DNA) was subcloned into pGEM-1 (Promega, Heidelberg, Germany). A complete human gastrin minigene was then created by cloning a $1.5-\mathrm{kb}$ EcoRI-BamHI fragment (containing $1.3 \mathrm{~kb}$ of $5^{\prime}$ flanking DNA, the first exon and part of the first intron) upstream of this reporter construct. This resulted in a $5.5-\mathrm{kb}$ human gastrin minigene lacking $\sim 1 \mathrm{~kb}$ in the first intron of gastrin.

Additional reporter constructs employed a $1.3-\mathrm{kb}$ human gastrin promoter fragment joined to the human growth hormone gene, and to the herpes simplex virus - thymidine kinase gene. These constructs were developed by subcloning a 1.4-kb EcoRI-PstI fragment of the gastrin promoter region and exon 1 (but not intron 1) in front of a standard promoterless human growth hormone construct (31) and in front of a promoterless HSV-1 thymidine kinase gene (32). The insulin-gastrin (INS-GAS) transgene, which targets expression of human gastrin to the pancreatic islets, has previously been described (6).

Injection fragments and microinjection techniques. DNA fragments for microinjection were prepared by restriction digest, gel electroelution, $\mathrm{CsCl}$ density gradient centrifugation, and dialysis against injection buffer as previously described (6). Microinjections into the male pronucleus of fertilized eggs from FVB inbred (Taconic Farms Inc., Germantown, NY) matings were also accomplished using standard approaches. Progeny were tested at $3 \mathrm{wk}$ of age for the presence of the transgene by Southern blot analysis. Probes used in these analyses were the product of Klenow labeling using random priming of the injection fragments.

Northern blot and RNase protection analyses. RNA was isolated from the indicated tissues by the guanidine thiocyanate method (33). RNA blots were performed by standard techniques using $10 \mu \mathrm{g}$ of total RNA in each lane. Tissue RNA isolated from transgenic mice expressing the human gastrin minigene was probed with an antisense RNA probe specific for exon 2 of human gastrin that did not crosshybridize with endogenous mouse gastrin mRNA. RNA isolated from the gastrin-hGH and gastrin-HSV-tk mice was probed with an antisense RNA probe specific for Exon I of the human gastrin gene that also did not crosshybridize with endogenous mouse gastrin mRNA.
RNA was analyzed by RNase protection analysis (RPA) as previously described (34). The probe in this assay was an antisense RNA probe corresponding to the AvaI-HincII fragment of the human gastrin gene. This fragment contains the basal human gastrin promoter and exon I (human gastrin sequences -194 to +54 ).

Histological evaluation and BrdU immunocytochemistry. 1-yr-old, nonfasted animals were killed for analysis of histology and proliferation indices. The experimental groups included five INS-GAS mice (three males, two females) and six hGAS mice (three males, three females). The control group included five age-matched, wild-type FVB mice (three males, two females). Before they were killed, animals received a single injection of 5-bromo- $2^{\prime}$-deoxyuridine $(\mathrm{BrdU})^{1}(50 \mathrm{mg} /$ $\mathrm{kg}$ i.p.) from a freshly made stock solution $(5 \mathrm{mg} / \mathrm{ml})$ dissolved in phosphate-buffered saline (PBS). The mice were killed $1 \mathrm{~h}$ later. Samples were placed in a cassette, fixed in Carnoy's fixative overnight, and embedded in paraffin wax. Tissues were then sectioned at $5 \mu \mathrm{m}$; some sections were stained with hematoxylin and eosin $(H \& E)$, while others were stained for BrdU incorporation.

Immunohistochemical detection of the BrdU incorporation was performed on 4- $\mu \mathrm{m}$ sections and visualized using the following avidin-biotin monoclonal antibody immunohistochemical technique. After deparaffinization in xylene through to alcohol, endogenous peroxidase activity in the tissue section was blocked by immersing the slides in $1 \%$ hydrogen peroxide in methanol. The slides were then washed in tap water. The BrdU monoclonal antibody identifies single stranded DNA only. Denaturation of the tissue DNA was achieved by incubation in $1 \mathrm{M}$ hydrochloric acid $(\mathrm{HCl})$ at $60^{\circ} \mathrm{C}$ for $8 \mathrm{~min}$. The slides were washed in tap water, tris-buffered saline (TBS), and incubated with $5 \%$ normal rabbit serum to block nonspecific binding of the primary antibody. The tissue was then incubated with the monoclonal antibody to BrdU (DAKOPATTS, Copenhagen, Denmark) diluted to 1:40 in tris buffer (TB). Control slides, incubated in each assay, were incubated with mouse serum. The slides were again washed in TBS, and incubated with biotinylated anti-mouse $\operatorname{IgG}(1$ : 200 in TB). After further washings in TBS, slides were incubated with peroxidase-conjugated streptavidin (1:400 in TB) washed in TBS and the labeled cells were visualized by the diaminobenzidine reaction and lightly counterstained with hematoxylin. The nucleus of cells at $\mathrm{S}$-phase of the cell cycle during the in vivo incorporation phase were stained with brown.

LI percentage was measured by counting the number of BrdUpositive cells and expressing the result as a percentage ratio of the total number of cells.

Measurement of colon crypt depth. Colon crypt depths were measured using a calibrated ocular reticle. For each animal, a series of crypt measurements were made from longitudinally sectioned crypts. To minimize sampling bias, the crypts were spaced approximately at $1 \mathrm{~mm}$ intervals along the mucosa, distal to the colonic ampula. The mean crypt depth was calculated from the series of measurements and were compared by the Student's $t$ test, relative to the experimental group.

In situ hybridization. In situ hybridization was performed on tissues obtained from the human gastrin minigene mice using ${ }^{35} \mathrm{~S}$-labeled riboprobes transcribed from DNA templates by SP6 (antisense) and T7 (sense) polymerase using 150 nucleotides of human gastrin exon 2 sequences (35). 4- $\mu \mathrm{m}$ sections were mounted on glass slides, dewaxed and rehydrated in PBS. Sections were then permeabilized with proteinase $\mathrm{K}$, post-fixed in $4 \%$ paraformaldehyde, acetylated, and then hybridized overnight with the labeled probes. Sections were hybridized by incubating the tissue overnight at $55^{\circ} \mathrm{C}$ in a $25-\mathrm{ml}$ solution containing $0.02 \%$ Denhardt's, $10 \%$ dextran sulfate, $50 \%$ formamide, $0.3 \mathrm{mg} / \mathrm{ml}$ bovine rRNA, $10 \mathrm{mM}$ dithiothreitol, $300 \mathrm{mM} \mathrm{NaCl}, 10 \mathrm{mM}$ $\mathrm{Na}_{2} \mathrm{HPO}_{4}, 10 \mathrm{mM}$ Tris- $\mathrm{HCl}$, and $5 \mathrm{mM}$ EDTA plus $1 \times 10^{6} \mathrm{cpm}$ of ${ }^{35} \mathrm{~S}$-labeled riboprobe. After washing with increasing stringency to 0.5

1. Abbreviations used in this paper: $\mathrm{BrdU}, 5$-bromo-2'-deoxyuridine; CCK, cholecystokinin; LI, labeling index. 
$\times \mathrm{SSC}$, the tissues were dehydrated in alcohol containing $0.3 \mathrm{M}$ ammonium acetate. The sections were then dipped in NBT-2 emulsion (Eastman Kodak Co., Rochester, NY) and exposed for 6-10 d before development of silver grains with Kodak D-19. Sections were counterstained with hematoxylin and eosin.

Extraction and assay of progastrin-derived peptides. Tissue samples $(100 \mathrm{mg}$ ) were routinely boiled in $1 \mathrm{ml}$ water, homogenized, and centrifuged $(10,000 \mathrm{~g}, 1 \mathrm{~min})$. The supernatant was recovered and frozen for subsequent analysis by radioimmunoassay. Serum was obtained by bleeding following retroorbital puncture under ether anesthesia. Samples were assayed (23) for: (a) human progastrin using rabbit antiserum L289 raised to human preprogastrin Tyr* 93-101 which reacts fully with human preprogastrins 93-101 and 76-101 but does not react with the $\mathrm{COOH}$-terminal tryptic peptide-human preprogastrin 96-101-or with wild-type mouse antral extracts; (b) $\mathrm{COOH}$-terminally amidated gastrins using rabbit antiserum L2 which reacts similarly with $\mathrm{G} 17$ and $\mathrm{G} 34$ but not with $\mathrm{COOH}$-terminally extended gastrins; (c) $\mathrm{COOH}$-terminal Gly-extended gastrins using monoclonal antibody 109-21 (generous gift of Dr. J.H. Walsh, CURE/ UCLA, Los Angeles, CA) which reacts with Gly- but not COOH-terminally amidated gastrins; and $(d)$ intact human G17 using rabbit antiserum L6 raised to G17 which reacts with intact human G17, but not with rodent $\mathrm{G} 17$, or with $\mathrm{COOH}$ - or Nh3-terminally extended or truncated forms of human G17. Assays of plasma gastrins included a standard curve prepared in mouse plasma stripped of gastrin.

Biosynthetic labeling experiments. The biosynthesis of progastrin in liver was examined by incorporation of $\left[{ }^{35} \mathrm{~S}\right]$ sulphate and $\left[{ }^{3} \mathrm{H}\right] \mathrm{Tyr}$ into tissue samples incubated in vitro as previously described $(12,36)$. Progastrin was pulse-labeled during incubation at $22^{\circ} \mathrm{C}$ for $2 \mathrm{~h}$ and then chased at $37^{\circ} \mathrm{C}$ for up to $3 \mathrm{~h}$. Tissue was extracted as described above, and progastrin-derived peptides in both tissue extracts and media were purified by immunoprecipitation using the following antibodies: L382, specific for intact human progastrin; L109, specific for $\mathrm{COOH}$-terminally amidated gastrins; and L373, specific for Glyextended gastrins. In each case, $50 \mu \mathrm{l}$ of antiserum was added to the samples in $1.0 \mathrm{ml} 0.02 \mathrm{M}$ phosphate buffer, $\mathrm{pH} 7.4$, containing $15 \mu \mathrm{l}$ liquid BSA (stock 22\% vol/vol; Advanced Protein Products, Ltd., Brierly Mill, West Midlands, UK) together with $200 \mu$ l goat anti-rabbit precipitating antibody (Incstar Corp., Stillwater, MN). Precipitates were allowed to form at $4^{\circ} \mathrm{C}$ overnight, and were recovered by centrifuging at 3,000 $\mathrm{g}$ for $10 \mathrm{~min}$. Precipitates were washed five times by resuspension in $3 \mathrm{ml} 0.02 \mathrm{M}$ phosphate buffer, $\mathrm{pH} 7.4$, containing $0.75 \% \mathrm{vol} / \mathrm{vol}$ liquid BSA, and after the final wash were solubilized by boiling in $1 \mathrm{ml}$ water. The supernatant from the first precipitation was briefly boiled to denature any remaining immunoglobulin, cooled, and then taken for precipitation with the next antibody. Pilot experiments showed that similar patterns of recovery were obtained regardless of the order in which antibodies were used in serial precipitations. The specificity of antibodies used for precipitation was verified by radioimmunoassay of solubilized precipitates.

HPLC. Tissue extracts and the immunoprecipitates from biosynthetic labeling experiments were fractionated by HPLC. Both types of sample were clarified by centrifugation at 100,000 $g$ for $1 \mathrm{~h}$ and applied to 8- $\mu$ PLRP-S (Polymer Laboratories, Church Stretton, UK) equilibrated with $0.05 \mathrm{M}$ ammonium bicarbonate and eluted with a gradient of acetonitrile at flow rate of $1 \mathrm{ml} \cdot \mathrm{min}^{-1}$. Samples were collected for radioimmunoassay using antibodies described above. In biosynthetic labeling experiments a portion (usually 850 $\mu \mathrm{l} \cdot \mathrm{min}^{-1}$ ) of the eluate was diverted for on-line scintillation counting using a Radiomatic detection system (Canberra-Packard, Pangbourne, UK) and an update time for counting of $15 \mathrm{~s}$. In control sepa-

Figure 1. (A) Diagram of human gastrin transgenes. hGAS-hGAS contains the $1.3 \mathrm{~kb}$ human gastrin promoter and human gastrin intragenic sequences. hGAS-hGH contains the same human promoter joined to the human growth hormone gene. hGAS-TK contains the
A

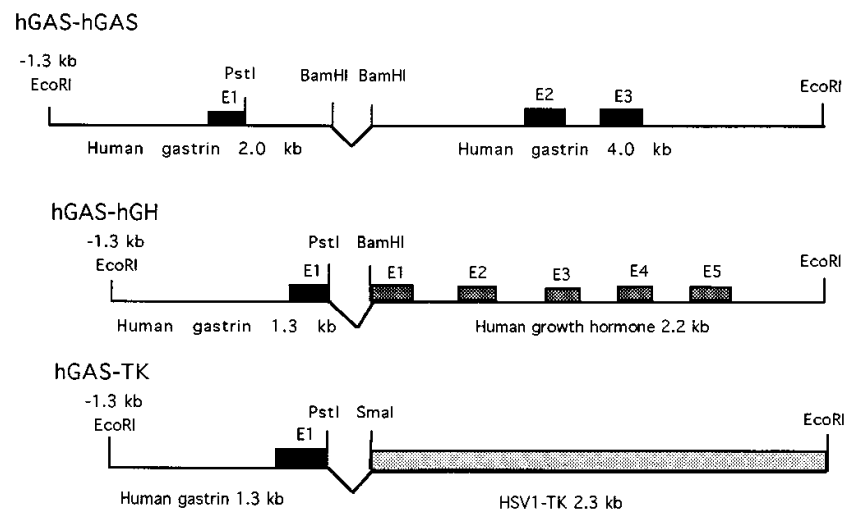

B

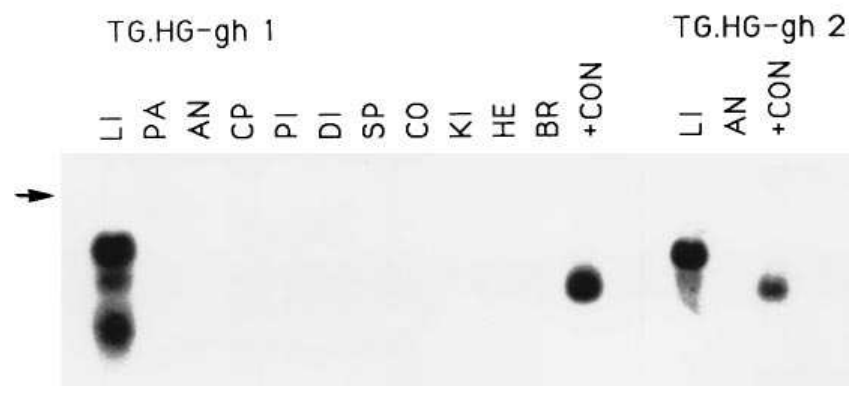

C

\section{TG.HG-tk 1}

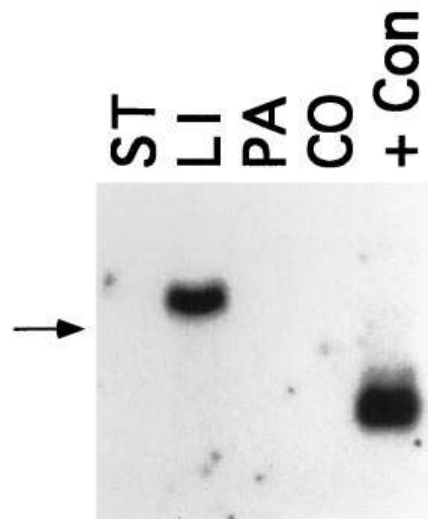

same human gastrin promoter joined to the herpes simplex virus 1-thymidine kinase gene. Location of restriction sites and exons are also shown. (B) Northern blot analysis of hGAS-hGH transgenic mice. Northern blots were used to assess expression of chimeric human gastrin-human growth hormone mRNA in $20 \mu \mathrm{g}$ of total RNA isolated from adult hGAS-hGH (TG.HG-gh 1 and TG.HG-gh 2) transgenic lines using a human gastrin exon I riboprobe. The chimeric message was larger than the human gastrin mRNA positive control. LI liver, PA pancreas, AN antrum, CO corpus, PI proximal intestine, DI distal intestine, SP spleen, CO colon, KI kidney, HE heart, and BR brain. The positive control was a $\mathrm{GH}_{4}$ cell line transfected with the human gastrin gene. The arrow indicates the position of $18 \mathrm{~S}$ ribosomal RNA. $(C)$ Northern blot analysis of hGAS-TK transgenic mice. Northern blots were used to assess expression of chimeric human gastrin thymidine kinase mRNA in $20 \mathrm{mg}$ of total RNA isolated from adult hGAS-TK (TG.HG-tk 1) transgenic line. The blots were probed with a human gastrin exon 1 riboprobe. The chimeric message was larger than the human gastrin mRNA positive control. 
rations, a spillover of $30 \%$ of ${ }^{35} \mathrm{~S}$ counts into the ${ }^{3} \mathrm{H}$ channel was found and all data were corrected for this.

\section{Results}

The human gastrin promoter region targets adult liver. $\mathrm{A}$ human gastrin minigene was created which contained $1.3 \mathrm{~kb}$ of $5^{\prime}$ flanking DNA, $2 \mathrm{~kb}$ of $3^{\prime}$ flanking DNA, all three exons and most of the intronic sequences (Fig. $1 A$ ), as previously described. In a previous study, we showed that the human gastrin minigene targeted expression to adult mouse liver and was not expressed in adult stomach, pancreas, or colon (35). Therefore, to determine whether intragenic sequences affected regulation of gastrin gene expression, human growth hormone (hGH) and the Herpes simplex virus thymidine kinase (HSV-tk) were used as reporter genes in additional human gastrin promoter

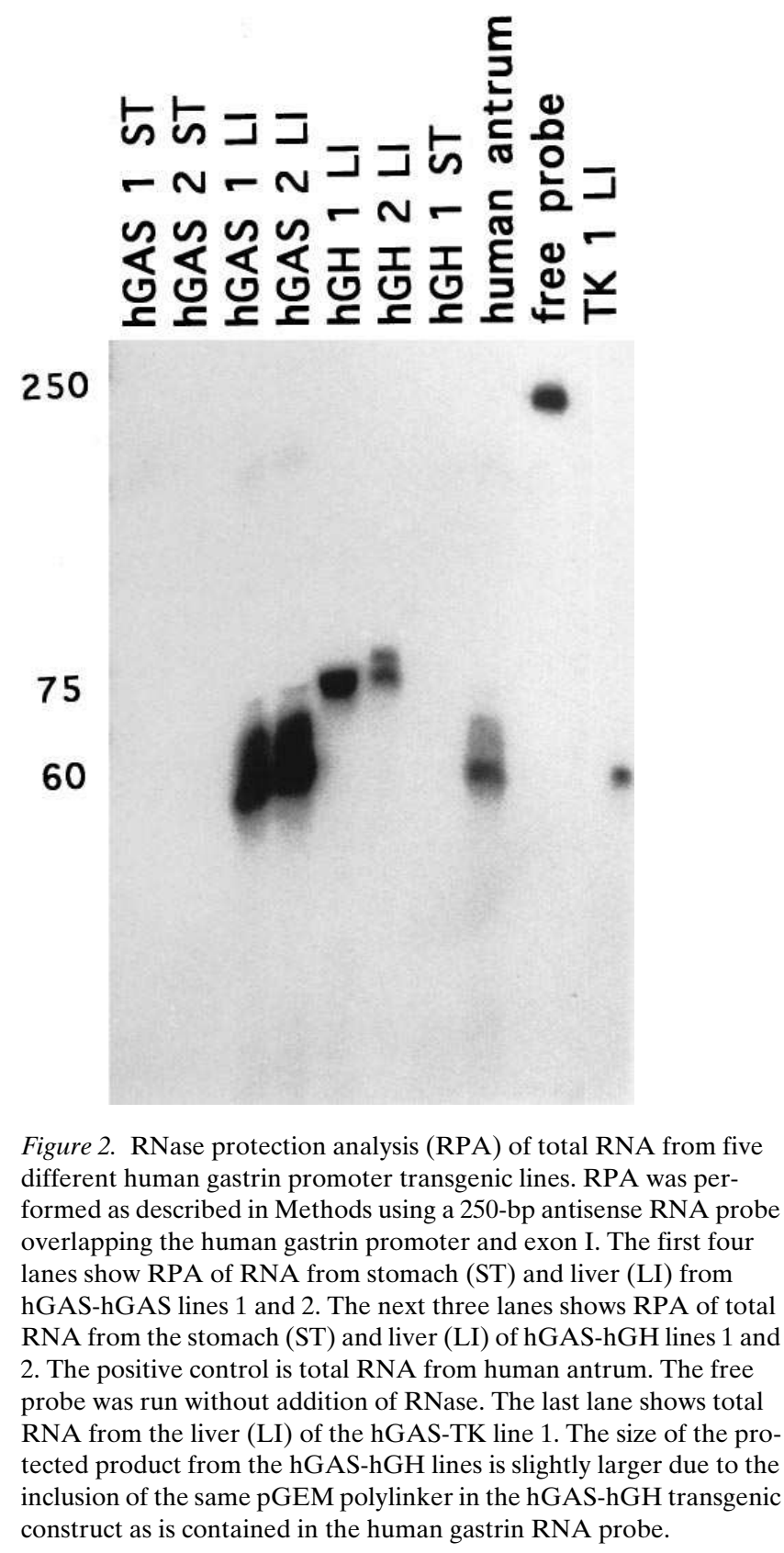

constructs (hGAS-hGH and hGAS-tk; Fig. $1 A$ ). Two lines containing the human growth hormone gene (TG.HG-gh 1 and TG.HG-gh 2) and one line containing the Herpes thymidine kinase gene (TG.HG-tk 1) were created using standard methods. In all three transgenic lines, the $1.3 \mathrm{~kb}$ human gastrin promoter targeted expression of the reporter gene to the adult liver but not to adult stomach in an identical fashion (Fig. $1 B$ ), similar to the pattern seen with the human gastrin minigene.

A more sensitive RNase protection assay confirmed that these mice exhibited liver-specific expression and the absence of expression in stomach. As shown in Fig. 2, a high degree of expression was found in liver tissues from all five of the human gastrin promoter transgenic lines compared in this experiment. Utilization of the same transcription start site was confirmed in the RNase protection experiments (Fig. 2). This suggests that the liver-specific expression seen in these transgenic mice represents activity of the authentic human gastrin promoter.

A

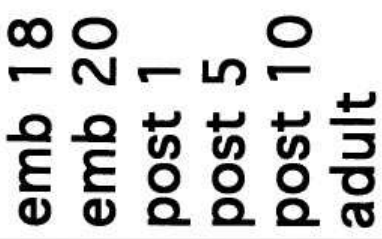

hGAS

GAPDH

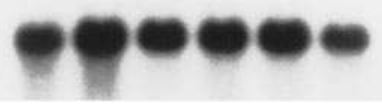

B

hGAS
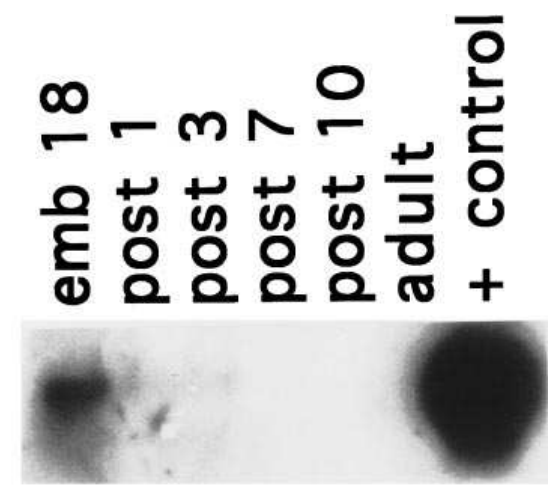

GAPDH

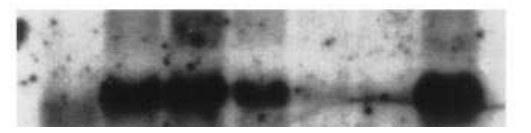

Figure 3. Expression of the human gastrin mRNA in liver and pancreas of hGAS transgenic mice during development. Northern blots of total RNA were probed with the human gastrin (hGAS) antisense Exon II riboprobe, or a random-primed GAPDH probe. $(A)$ Expression of human gastrin mRNA in liver. (Top) Human gastrin mRNA. (Bottom) GAPDH mRNA. (B) Expression of human gastrin mRNA in pancreas. (Top) Human gastrin mRNA. (Bottom) GAPDH mRNA. 

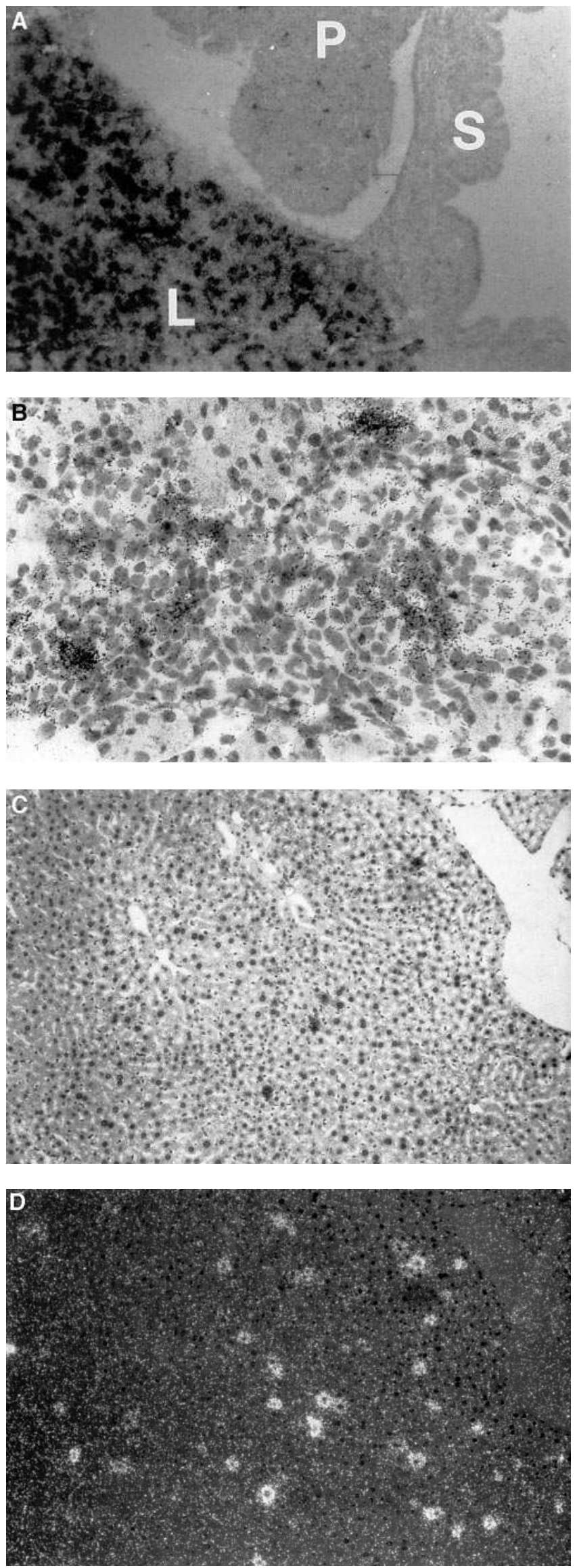

The human gastrin minigene is expressed transiently in fetal pancreatic islets. In order to study the expression of the human gastrin transgene during development, Northern blot analysis was performed on total RNA prepared from pancreas, liver, and stomach from late fetal and early adult stages (Fig. 3). Human gastrin minigene expression could be detected in the transgenic mouse liver as early as day 18, and expression continued throughout the postnatal period into adult, although a slight decrease was seen at the time of birth (Fig. $3 A$ ). In contrast, human gastrin minigene expression was present in the transgenic pancreas in the late fetal period (day 18), but decreased at the time of birth and disappeared by postpartum day 10 (Fig. 3 B). No human gastrin transgene expression could be detected in the stomach during development, and no expression was noted in nontransgenic tissues (data not shown)

Human gastrin transgene expression during development was further analyzed using in situ hybridization (Fig. 4). These experiments clearly demonstrated transgene expression in islet and duct cells at day 18 of fetal development (Fig. 4, $A$ and $B$ ). No gastrin-specific hybridization was seen over acinar cells. The islet-associated expression decreased by day 3 postpartum and was absent from pancreas at day 10 of life (data not shown). Moreover, the endogenous mouse gastrin expression followed an identical pattern of expression (data not shown).

We further analyzed the pattern of expression of the transgenic mRNA in specific cell types in the liver (Fig. $4 A, C, D$ ). This expression was clearly confined to a subset of hepatocytes that was neither peri-portal nor centrilobular in location, but in an intermediate location. This expression was highest and most widespread in utero and declined postpartum. Furthermore, expression was limited to only about $1-2 \%$ of hepatocytes in the adult liver. In contrast, no endogenous mouse gastrin gene expression could be found in the same cells.

Human progastrin is poorly processed by the liver, but is cleaved and amidated by the pancreatic islets. The concentration of human progastrin immunoreactivity in extracts of the liver of hGAS transgenic mice was $4.5 \mathrm{nmol} \cdot \mathrm{g}^{-1}$, but concentrations of Gly-extended or amidated gastrins were less than $0.01 \mathrm{nmol} \cdot \mathrm{g}^{-1}$. After reversed phase HPLC, liver extracts from hGAS transgenics were found to contain a single major peak of human progastrin-like immunoreactivity that had the retention time of native, intact, human progastrin (Fig. 5). Consistent with the results of Northern blots and in situ hybridization data, concentrations of human progastrin immunoreactivity were $<10 \mathrm{pmol} \cdot \mathrm{g}^{-1}$ in extracts of brain, pancreas, stomach, small or large intestine of hGAS transgenic mice. In contrast, extracts of the pancreas of INS-GAS transgenic mice contained high concentrations of the posttranslationally processed

Figure 4. Expression of the human gastrin promoter in the pancreas and liver of hGAS transgenic mice. In situ hybridization was performed using the human gastrin antisense Exon II riboprobe. $(A)$ Sagittal section of fetal transgenic mouse at day 18 of gestation probed for the transgene. The liver $(\mathrm{L})$, pancreas $(\mathrm{P})$, and stomach $(S)$ are identified. (B) High magnification of fetal pancreas shown in $A$ demonstrating immature islet tissue in the center of the field, surrounded by acinar tissue. Gastrin expression is seen only over proliferating islet precursors; acinar cells are devoid of expression. $(C)$ Adult liver, brightfield. $(D)$ Adult liver, darkfield. Hematoxylin and eosin. $A, C$, and $D \times 80, B \times 320$. 

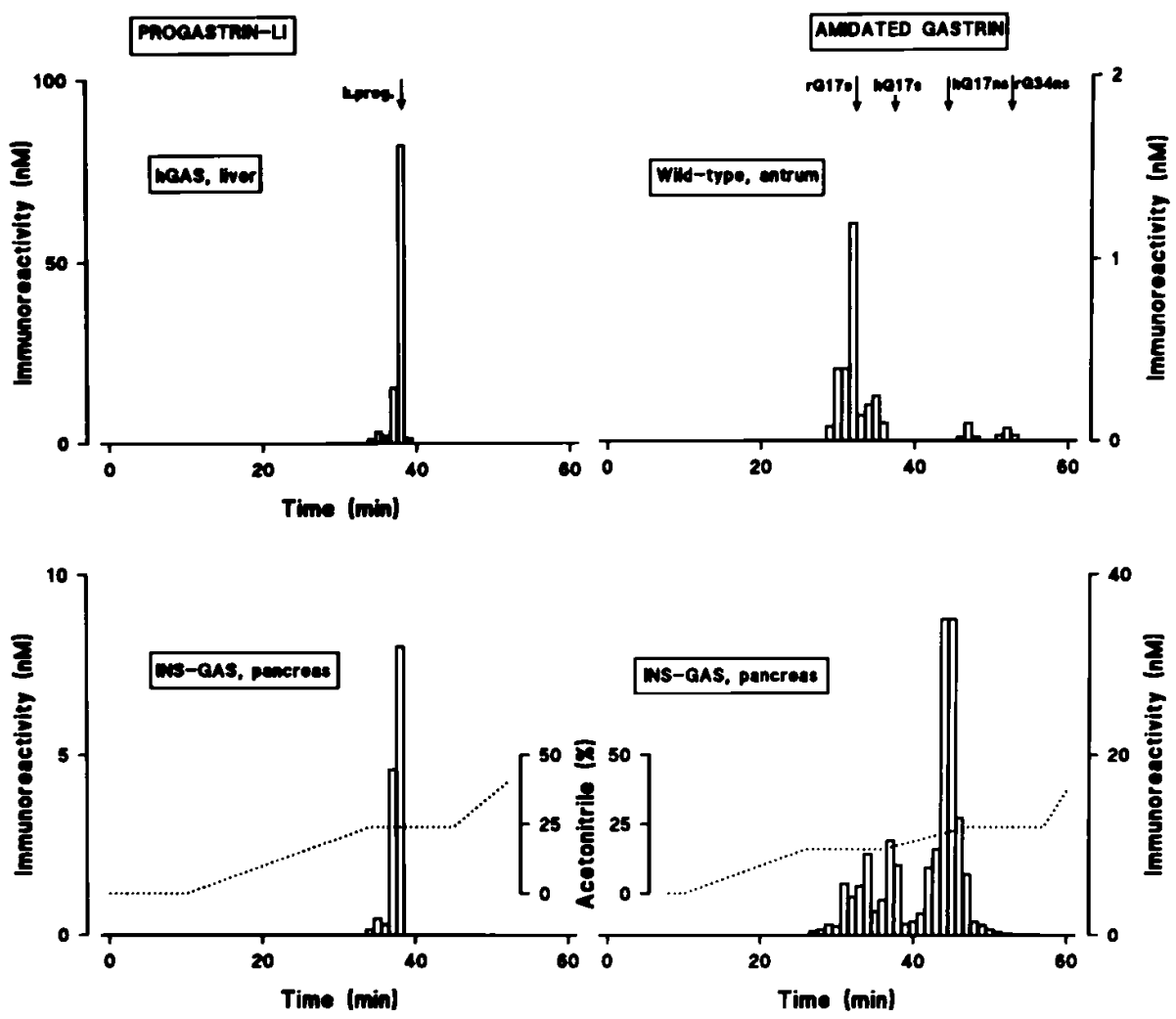

Figure 5. HPLC separation of immunoreactive gastrins in extracts of liver, pancreas, and antrum. Reversed phase HPLC of tissue extracts and radioimmunoassay of the eluates show that the material corresponding to intact progastrin (left) occurs in liver extracts of hGAS mice (top) and pancreas in INS-GAS mice (bottom). Amidated gastrin (right) is found mainly as sulfated G17 in wildtype antrum (top); in the pancreas of INS-GAS mice the major amidated peptide corresponds to human sulfated G17 (bottom). Arrows at the top indicate elution positions of human progastrin (h.prog), sulfated rodent G17 (rG17s), sulfated human G17 (hG17s), unsulfated human G17 (hG17ns), and unsulfated rodent G34 (rG34ns). Broken line indicates gradient of acetonitrile in $0.05 \mathrm{M}$ ammonium bicarbonate. gastrins (Table I). The concentrations of amidated gastrin exceeded those in the antrum of wild-type mice; as expected, progastrin and its derivatives were undetectable in the pancreas of wild-type adult mice. Human progastrin- and Glyextended gastrin immunoreactivities were detected in pancreatic extracts of INS-GAS mice in concentrations that were about fivefold lower than those of amidated gastrin (Table I). Two lines of evidence indicate that a high proportion of amidated gastrin in INS-GAS mouse pancreas can be attributed to human unsulphated G17. First, antibody L6, which reacts specifically with human G17 but not with mouse gastrin, measured high concentrations of immunoreactivity in INS-GAS mouse pancreas, but as expected did not react with wild-type mouse gastrin in antral extracts (Table I). Second, on reversedphase HPLC using a gradient elution system that resolves rodent and human G17, the major peak of immunoreactivity in pancreatic extracts was compatible with unsulphated human G17; the remaining minor peaks of amidated corresponded to sulphated human G17 and possibly minigastrin (Fig. 5).

We considered the possibility that there might be rapid processing and secretion of progastrin by liver, which because of the absence of secretory granules did not result in the accumulation of detectable concentrations of processed products in tissue. Thus, in biosynthetic labeling experiments, we found progastrin in liver labeled with $\left[{ }^{35} \mathrm{~S}\right]$ sulfate and $\left[{ }^{3} \mathrm{H}\right] \mathrm{Tyr}$ (not shown) at the end of a pulse-labeling period, and in both tissue and medium during the chase (Fig. 6). We did not find labeled peptides corresponding to either amidated or Gly-extended gastrin at chase times up to $3 \mathrm{~h}$ when there was substantial secretion of labeled progastrin.

High serum levels of human progastrin leads to similar colonic growth effects compared to high serum levels of amidated gastrin. Plasma levels of human progastrin and amidated gastrin were measured in transgenic and wild type mice $(n=14$ 16) using region specific antibodies that were specific for progastrin (L289) and amidated gastrin (L2). Plasma levels of amidated gastrin were approximately twofold elevated in INSGAS mice (132 pM) compared to wild type ( $73 \mathrm{pM}, P<0.05$, $t$ test; Fig. 7). Plasma levels of amidated gastrin in hGAS mice (83 pM) were not significantly elevated compared to wild type controls. In contrast, plasma levels of progastrin were markedly elevated $(P<0.05$, Mann Whitney $U$ test $)$ in hGAS mice (mean \pm SEM $=20.1 \pm 10.6$ ) compared to wild type controls $(<0.5 \mathrm{nM})$, although there was variation between hGAS mice, as shown in Fig. 7. Plasma levels of progastrin in the INS-GAS

Table I. Concentrations of Progastrin-derived Peptides (nmol. ${ }^{-1}$ ) Measured With Four Antibodies in Extracts of the Pancreas from hGAS and INS-GAS Transgenic Mice $(n=4)$ Compared with Wild Type Pancreas and Antrum*

\begin{tabular}{lcccc}
\hline & \multicolumn{4}{c}{ Antibody } \\
\cline { 2 - 5 } Tissue & L289 & L2 & mAb 109-21 & L6 \\
\hline INS-GAS, pancreas & $1.4 \pm 0.1$ & $7.1 \pm 1.6$ & $1.6 \pm 0.6$ & $5.5 \pm 2.0$ \\
hGAS, pancreas & $<$ & $<$ & $<$ & $<$ \\
hGAS, liver & $4.5 \pm 1.1$ & $<$ & $<$ & $<$ \\
Wild type, pancreas & $<$ & $<$ & $<$ & $<$ \\
Wild type, antrum & $<$ & $1.5 \pm 0.2$ & 0.05 & $<$ \\
Wild type, antrum & $<$ & $<$ & $<$ & $<$ \\
& & & & \\
\hline
\end{tabular}

* Mean $\pm \mathrm{SE}<$, indicates below the limit of detection (set at 10 pmol.g $\left.{ }^{-1}\right)$. 


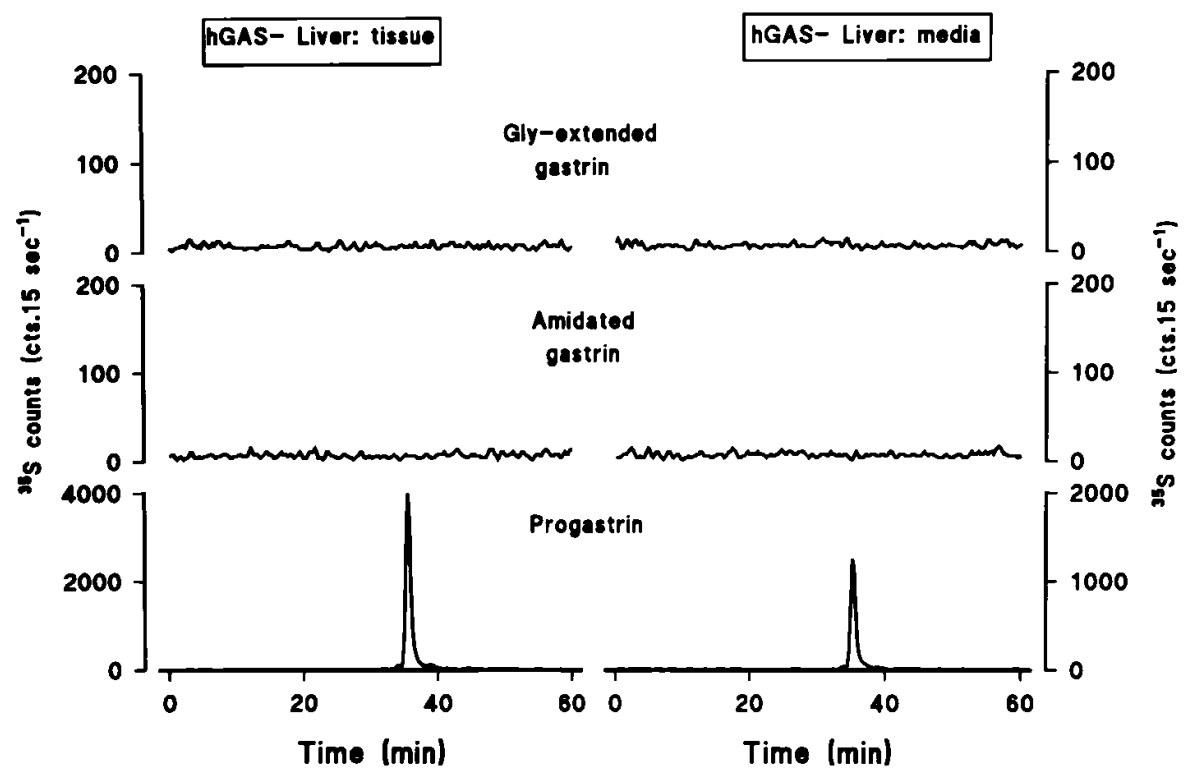

Figure 6. HPLC separation and on-line scintillation counting of immunoprecipitates from pulse-chase studies of liver. After pulse labeling with $\left[{ }^{35} \mathrm{~S}\right]$ for $2 \mathrm{~h}$ at $22^{\circ} \mathrm{C}$ and chasing at $37^{\circ} \mathrm{C}$ for $1 \mathrm{~h}$, labeled progastrin (bottom) was identified in immunoprecipitates from tissue extracts (left) and in media (right). In contrast, immunoprecipitates obtained using antibodies to amidated gastrin (middle), or Glyextended gastrins (top), did not reveal labeled peptides at chase times of 1 or $3 \mathrm{~h}$, in tissue or media. See Fig. 5 for details of HPLC gradient.

mice were no different from wild type controls (data not shown).

The elevated levels of progastrin and amidated gastrin in these transgenic mice allowed us the opportunity to assess possible system effects of these peptides. To determine the effect of gastrin peptides on the growth of the gastrointestinal mucosa, BrdU was administered to nonfasted, 1-yr-old INS-GAS, hGAS, and wild type mice $1 \mathrm{~h}$ before the mice were killed. The average number of BrdU-labeled S-phase cells in the gastric and colonic mucosa was measured in 5-6 animals from each genotype (Table II). The labeling index was increased in both hGAS colon $(7.46+1.90 \%)$ and INS-GAS colon $(6.16+$ $1.17 \%)$ compared to wild type colon $(4.01+0.98 \%)(P<$ $0.05)$. The proliferative effects were observed in the proximal colon, the distal colon, and the rectum in the hGAS mice (Table II). Similar proliferative effects were observed in the proximal and distal INS-GAS colon, although the labeling index in the INS-GAS rectum was not statistically different from that of wild type mice. The proliferative zone in the hGAS colon (Fig. $8 B$ ) was expanded compared to that observed in wild type mouse colon (Fig. $8 A$ ), where the proliferative zone was polarized toward the base of the glands. In addition, the colonic glands of hGAS and INS-GAS mice (Fig. $9 B, C$ ) were somewhat elongated compared to those of age-matched, wild type mice (Fig. $9 A$ ). The mean colonic crypt depth of hGAS mice ranged from 193 to $224 \mu \mathrm{m}$ and that of INS-GAS mice ranged from 193 to $229 \mu \mathrm{m}$. Both experimental groups were significantly increased $(P<0.01)$ compared to that of wild type controls, which ranged from 135 to $168 \mu \mathrm{m}$.

The labeling index in the stomach of hGAS mice-both the gastric body and pylorus L.I.-was increased but not statistically different from that of wild type mice. There were qualitative differences in Brdu labeling, particularly in the pyloric region (Fig. $8 C, D$ ). In contrast, the mean gastric body labeling index was significantly increased in INS-GAS mice $(6.40 \pm 1.59 \%)$ compared to wild type control stomach

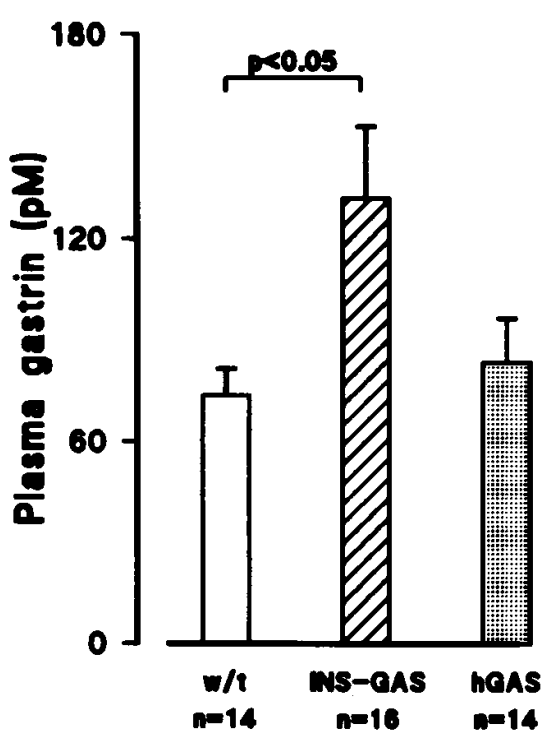

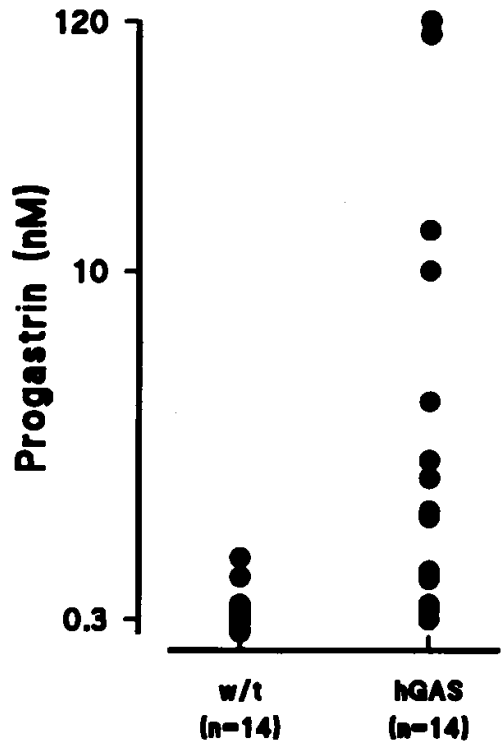

Figure 7. Plasma amidated gastrin and progastrin levels in INS-GAS, hGAS mice, and wild type mice. On the left are the plasma amidated gastrin levels $(\mathrm{pM})$ in 14 wild type mice, 16 INS-GAS mice, and 14 hGAS mice. The mean plasma levels were statistically different between INS-GAS and wild type. On the right are the plasma progastrin levels in 14 wild type and 14 hGAS transgenic mice. The progastrin levels were generally $<0.5$ in wild type mice, and much greater in hGAS transgenic mice. In all of 16 plasma samples from INS-GAS mice, progastrin was undetectable. 
Table II. Labeling Indices in Gastrin Transgenic Mice

\begin{tabular}{|c|c|c|c|}
\hline & Wild type & INS-GAS & hGAS \\
\hline Number of Mice & 5 & 6 & 6 \\
\hline \multicolumn{4}{|l|}{ Stomach } \\
\hline body (LI\%) & $3.46 \pm 1.89$ & $6.40 \pm 1.59 *$ & $4.15 \pm 0.97$ \\
\hline pylorus (LI\%) & $4.89 \pm 2.21$ & $4.67 \pm 1.26$ & $5.33 \pm 1.26$ \\
\hline total (LI\%) & $4.16 \pm 1.99$ & $5.58 \pm 1.35$ & $5.06 \pm 1.23$ \\
\hline \multicolumn{4}{|l|}{ Colon } \\
\hline proximal (LI\%) & $4.3 \pm 1.57$ & $6.81 \pm 1.35^{*}$ & $7.54 \pm 2.60 *$ \\
\hline distal (LI\%) & $3.77 \pm 0.60$ & $5.93 \pm 1.28 *$ & $7.96 \pm 2.86^{*}$ \\
\hline rectum $(\mathrm{LI} \%)$ & $4.37 \pm 1.95$ & $5.66 \pm 1.16$ & $6.80 \pm 1.39 *$ \\
\hline total $(\mathrm{LI} \%)$ & $4.01 \pm 0.98$ & $6.16 \pm 1.17 *$ & $7.46 \pm 1.90 *$ \\
\hline
\end{tabular}

$* P<0.05$ versus wild type
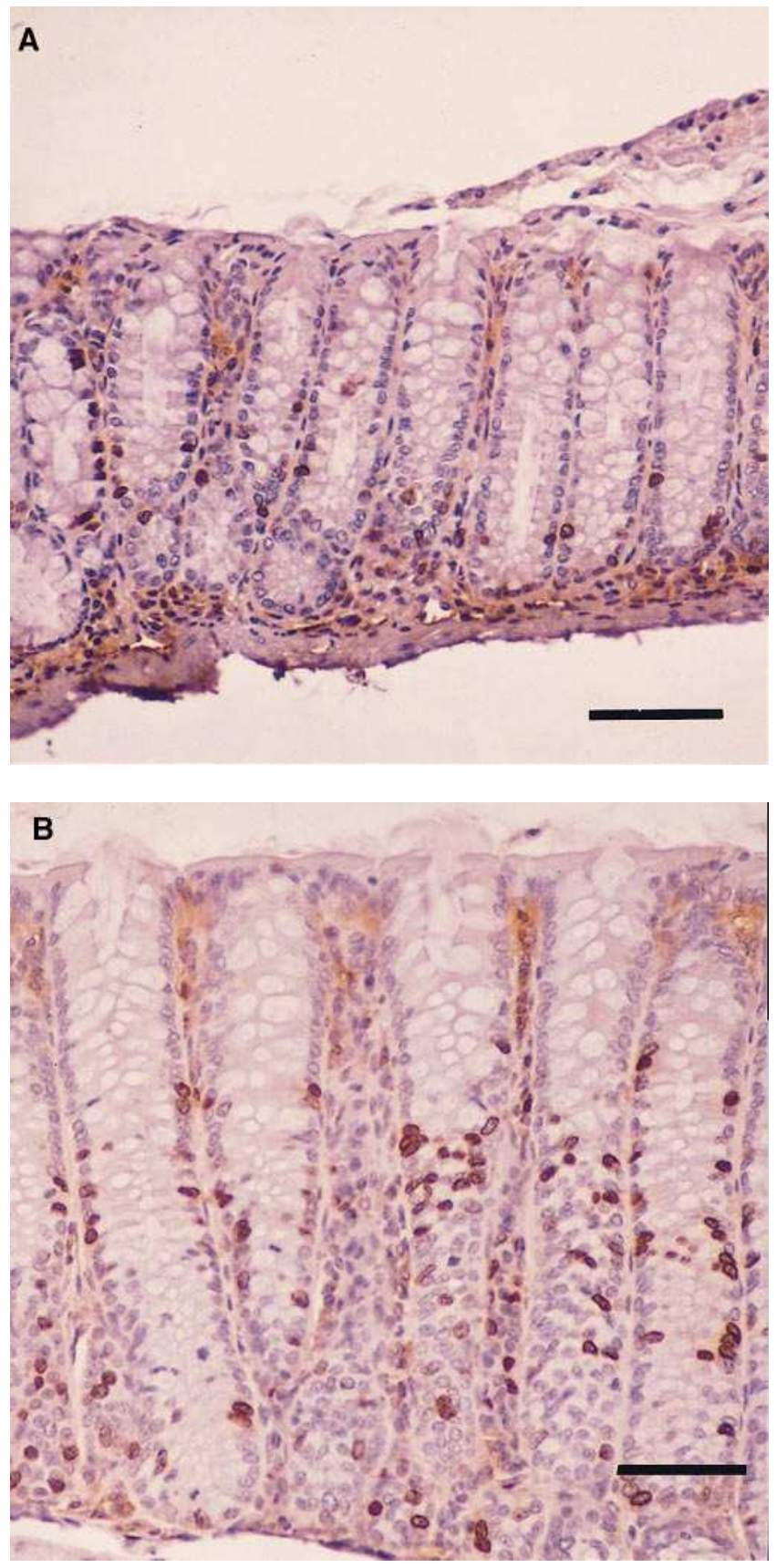

(3.46 $\pm 1.89 \%, P<0.05)$, while the labeling index in the pylorus of INS-GAS mice was identical to that of wild type controls. Histological examination of stomachs from 1-yr-old INS-GAS mice showed moderate to marked thickening of the fundic mucosa and multifocal hyperplasia (Fig. 10). Mild clonal expansion of enterochromaffin-like cells is suggested by frequent clusters of argyrophilic cells in the deep fundic mucosa of the transgenic mice (Fig. $11 B$ ) compared to wild type mice (Fig. $11 A$ ).

\section{Discussion}

This study demonstrates that the human gastrin $1.3 \mathrm{~kb}$ promoter contains sufficient DNA regulatory elements to direct expression of gastrin transiently to the fetal pancreatic islets. Expression of human gastrin mRNA was evident in embryonic

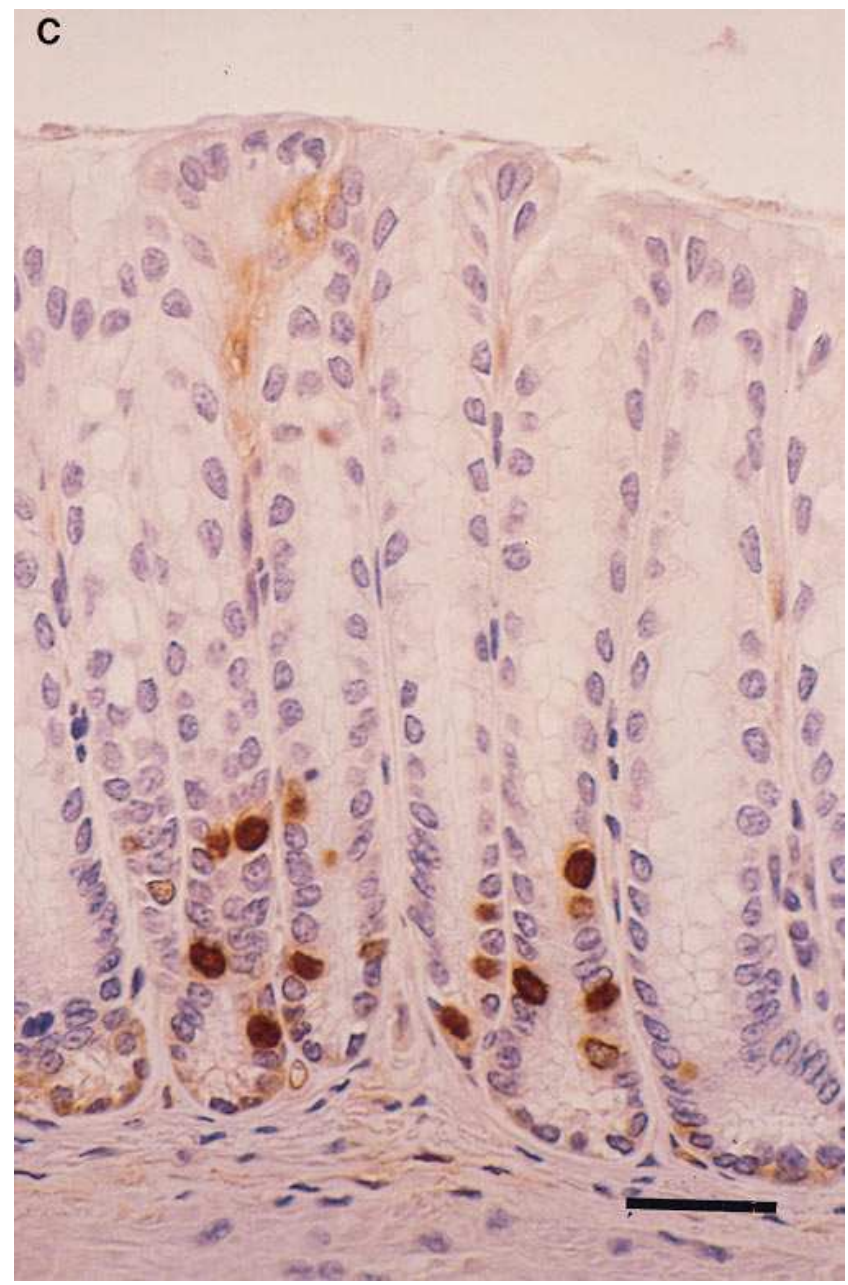

Figure 8. Comparison of mucosal epithelial BrdU label incorporation. BrdU incorporation detected by immunoperoxidase and diaminobenzidine. ( $A$ ) Wild type mouse colon. $(B)$ hGAS transgenic mouse colon. Crypt height, cell density per crypt and percentage of cells immunopositive for BrdU incorporation are increased. Bars in $A$ and $B$ represent $60 \mu \mathrm{m}$. (C) Wild type mouse pylorus. $(D)$ hGAS transgenic mouse pylorus. Percentage of cells immunopositive for BrdU incorporation is increased. Bars in $C$ and $D$ represent $30 \mu \mathrm{m}$. Hematoxylin counterstain. 

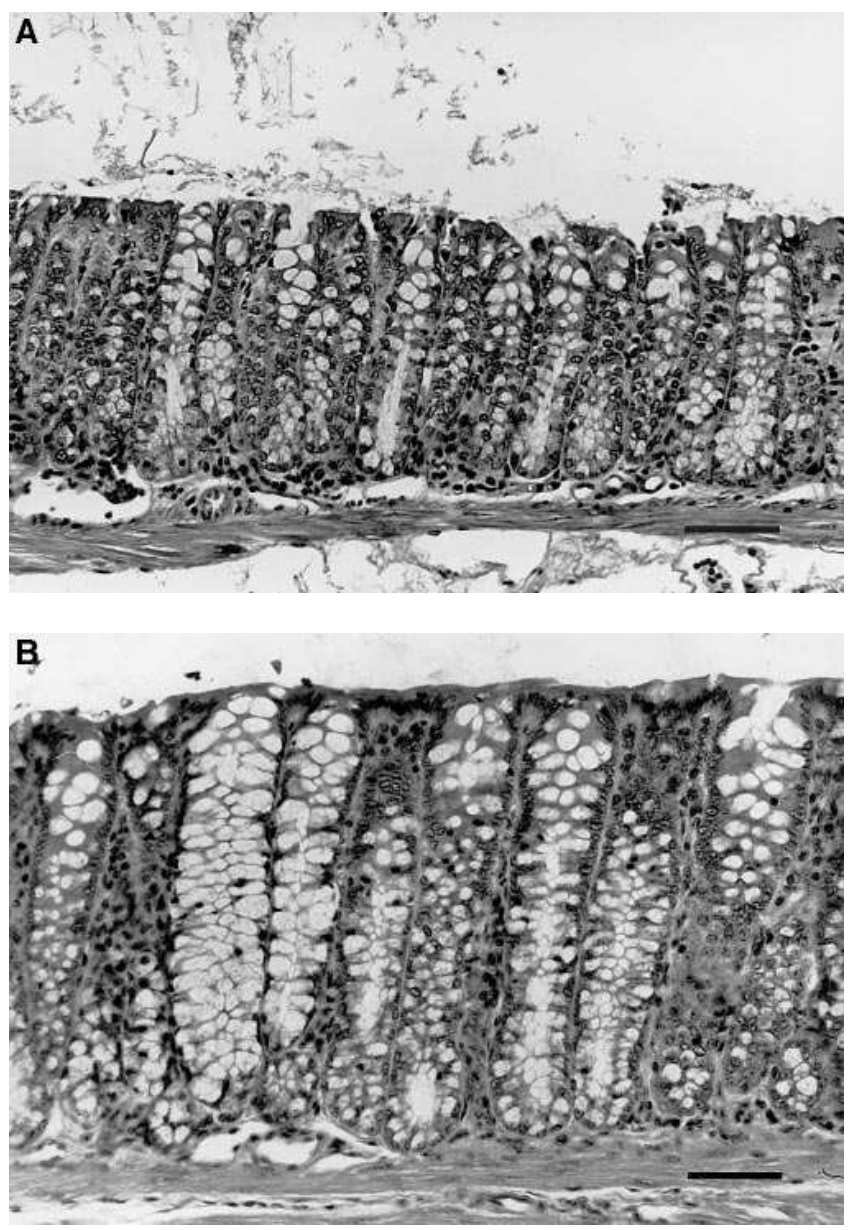

day 18 islets, but repressed at the time of birth and absent by postpartum day 7 . This pattern of transient gastrin expression in the neonatal pancreas during development has previously been described in the rat (5). Thus, our data with the human gastrin transgene supports previous in vitro (7-9) studies that suggested that the human gastrin promoter contains an isletspecific enhancer which may act as a molecular switch controlling gastrin gene transcription during pancreatic islet development. Although a previous in vivo study reported that a human gastrin $1.5 \mathrm{~kb}-\mathrm{SV} 40$ large $\mathrm{T}$ antigen construct did induce pancreatic islet cell tumors, the tumors did not express gastrin and the study was not able to distinguish between fetal or adult expression of the transgene because of the transforming nature of large $T$ antigen (37). In addition, our present results contrast with our previous study with the rat gastrin $450 \mathrm{bp}$ promoter, which did not achieve fetal islet expression (35).

An unexpected result was the liver-specific expression exhibited by the human gastrin promoter transgenes. Unlike the rat gastrin transgene (34), the human gastrin transgene was not active in the stomach, indicating that the stomach-specific enhancer is not located within $1.3 \mathrm{~kb}$ of $5^{\prime}$ flanking DNA. In a previous report, we noted the liver-specific expression in the two hGAS-hGAS lines (35). We now show using Northern blot analysis that three additional founder lines of mice containing $1.3 \mathrm{~kb}$ of human gastrin promoter, but not the intragenic sequences, demonstrated expression in the liver. This suggests that the cis-acting elements necessary for expression are contained entirely within the $1.3 \mathrm{~kb}$ human gastrin pro-

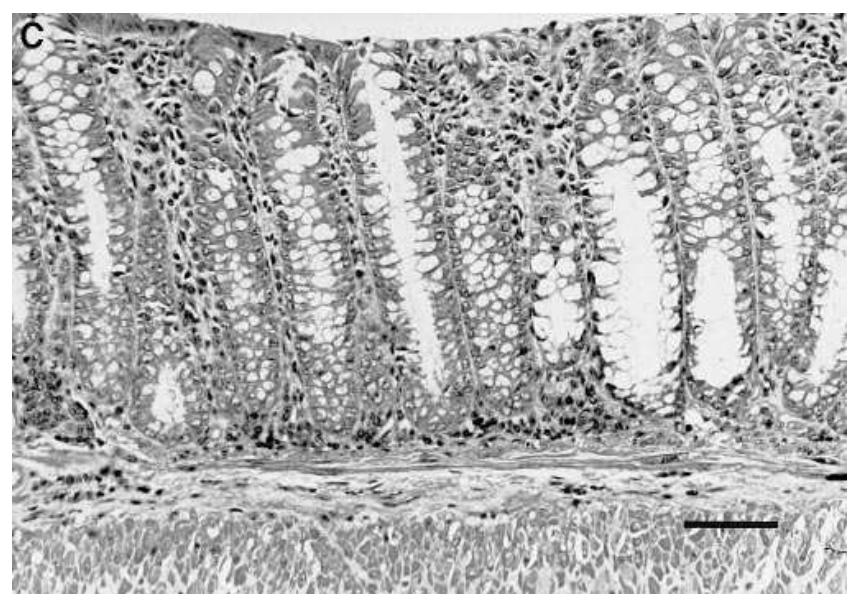

Figure 9. Histologic comparison of colonic mucosa. (A) Wild type. (B) hGAS transgenic. (C) INS-GAS transgenic. Mucosal hyperplasia manifested as increase in crypt height and cell density per crypt in $B$ and $C$. Goblet cell hypertrophy is prominent in $C$ and $B$. Bars represent $50 \mu \mathrm{m}$. Hematoxylin and eosin.

moter. In addition, RNase protection studies showed that in all five lines, the authentic human gastrin promoter was being utilized. Northern blot and in situ hybridization analysis revealed that expression of the hGAS-hGAS transgene in the liver could be seen as early as $18 \mathrm{~d}$ of gestation, but continued throughout development into the adult period. Although the expression of the human gastrin transgene in liver cells may represent an aberrancy due to species difference between the rodent and human, it is more likely due to the close developmental relationship between the liver and the pancreas (3841). The cis-acting elements targeting expression of human gastrin to the liver may be of value in identifying early events in liver differentiation.

Expression of the human gastrin minigene in the adult liver allowed us to compare the processing of human progastrin in two types of nontransformed cells: hepatocytes, which are nonendocrine cells, in the hGAS mice; and pancreatic islets, which are endocrine cells, in the INS-GAS mice. The processing of human progastrin generally occurs in a tissue-specific manner. For example, the gastric antrum synthesizes primarily G17, while the main molecular form in the duodenum and fetal pancreas is G34 (42). The gastrin gene is also expressed at the peptide level in several other cell types, such as the pituitary corticotrophs; however, these cell types appear to synthesize primarily unprocessed precursor forms of gastrin (43). Direct studies of gastrin posttranslation processing have been made in rat antral $\mathrm{G}$ cells $(12,36)$, but not as yet in other normal tissues expressing the gastrin gene. The processing of hu- 

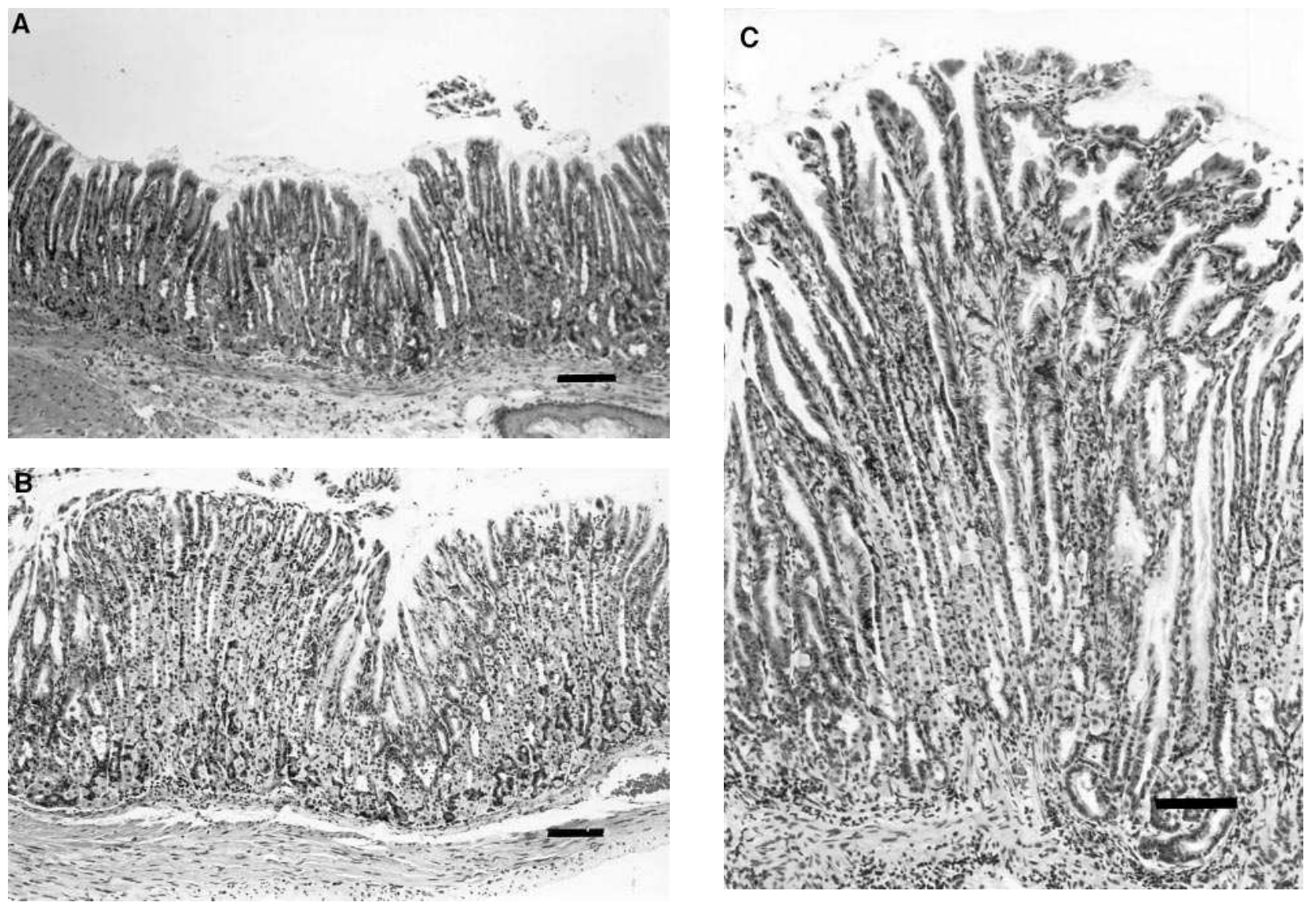

Figure 10. Histologic comparison of gastric mucosa. $(A)$ Wild type. $(B)$ hGAS transgenic. $(C)$ INS-GAS transgenic. Hypertrophy of the mucosa is evident in $B$ and, to a greater degree in $C$, associated with hyperplasia of oxyntic cells and the mucous epithelium. Bars represent $100 \mu m$. Hematoxylin and eosin.

man gastrin has been studied in vitro using the retrovirally expressed human gastrin cDNA in a number of endocrine and nonendocrine-derived transformed cell lines (13-17). These studies have, in general, suggested that human progastrin is poorly processed in nonendocrine cell lines that do not contain secretory granules, but well processed in most endocrine cell lines.

Therefore, our studies, which employed constructs containing the human gastrin genomic clone, have provided the first permanent transgenic mouse system with which to study the processing of human gastrin in vivo. Our studies confirm that nontransformed hepatocytes are unable to process progastrin, and support the concept that secretory granules are essential for posttranslation processing reactions such as prohormone endopeptidase cleavage and $\mathrm{COOH}$-terminal amidation (12, 36). In contrast, the pancreatic islets were able to carry out efficient processing of human progastrin, with the production of amidated gastrin. Interestingly, most of the gastrin produced was nonsulphated G-17, and thus the adult pancreatic islets appeared to process human gastrin much like antral $G$ cells, rather than like the fetal rat pancreas which produces mostly sulphated G-17 $(3,4)$, or gastrinomas seen in the ZollingerEllison syndrome, where human gastrin is often poorly processed $(10,44)$. Therefore, we would suggest that the pancreatic islets in the INS-GAS mouse are an excellent model for the antral $\mathrm{G}$ cell. All of the processing reactions which are known to occur in $\mathrm{G}$ cells also occur in pancreatic $\beta$ cells. The INS-GAS construct may provide a useful reagent to further analyze the amino acids and other molecular determinants which are important for processing of human progastrin.

In a previous study with the INS-GAS mice, we looked at the paracrine effects of amidated gastrin expression on growth of the pancreatic islets (6). We now show that serum levels are clearly elevated, and that a twofold elevation of serum amidated gastrin results in cellular proliferation in the oxyntic mucosa. The effects of hypergastrinemia have been studied to a limited extent in the mouse compared to the rat. Early studies with omeprazole suggested that sustained hypergastrinemia induced by inhibition of acid secretion results in oxyntic mucosal growth, manifested by increased mucosal weight and thickness, and increased ECL cell number (45). Our INS-GAS model of sustained hypergastrinemia differs from the omeprazole model in that the mice are not achlorhydric (data not shown). Further studies will be required to determine the effects of human G-17 overexpression on gastric acid secretion, and whether the mice are more susceptible to ulcer formation.

Perhaps the most interesting result of this study was that both the INS-GAS and the hGAS mice demonstrated an increased labeling index in the colonic mucosa compared to wild type mice. Until recently, the major target cells for the biological effects of gastrin peptides were believed to be the stomach, pancreas, and the central nervous system, all of which express 

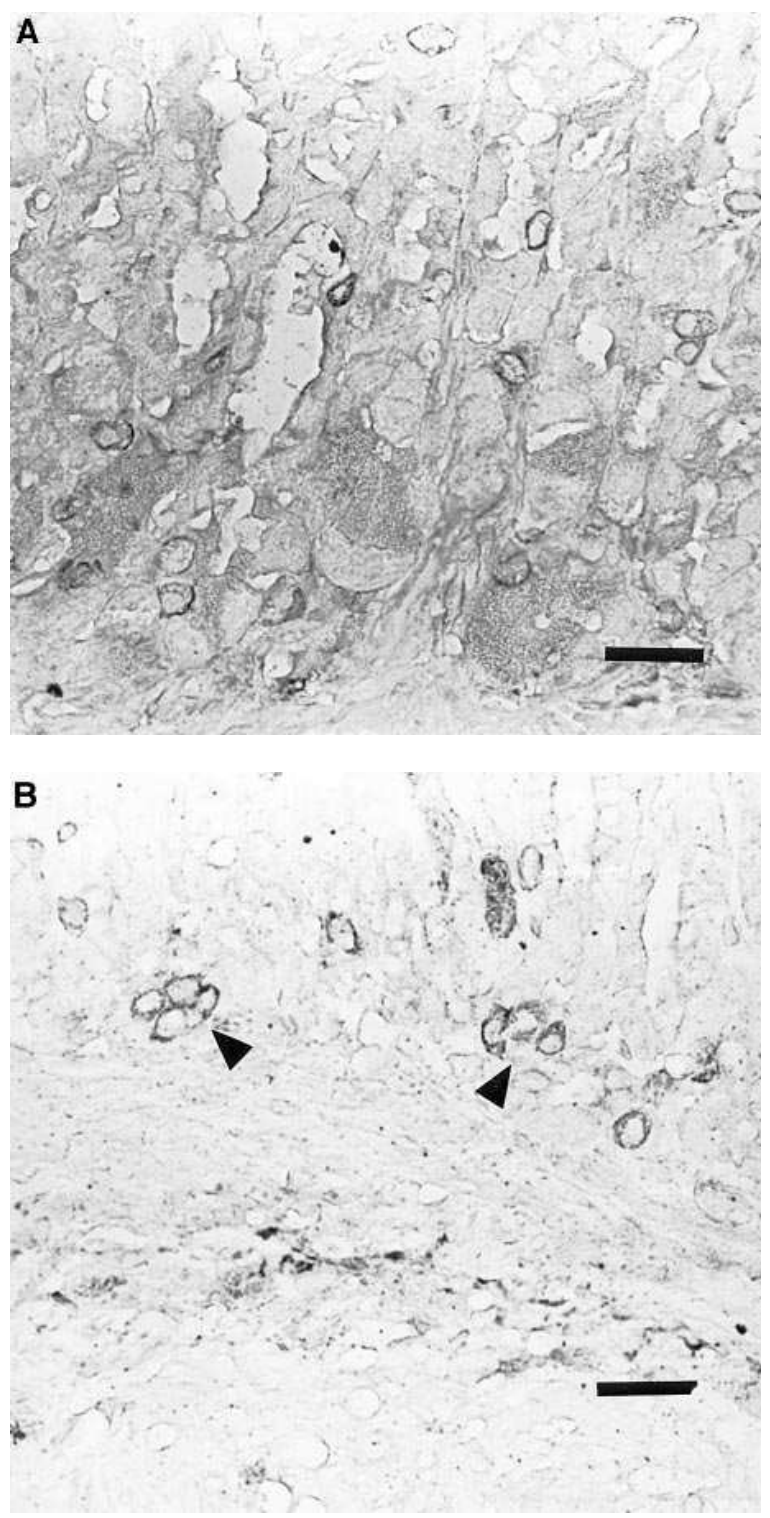

Figure 11. Argyrophilic cells in the fundic mucosa. (A) Wild type. $(B)$ INS-GAS transgenic. There are small clusters of 2-4 argyrophilic cells in the deep INS-GAS fundic mucosa (arrows). Bars represent 25 $\mu \mathrm{m}$. Grimelius stain.

cholecystokinin (CCK)-B receptors (46). However, several previous studies had shown that amidated gastrin may be mitogenic for normal intestinal mucosal cells and may enhance the growth of colon cancers or colon cancer cell lines $(47,48)$. In addition, gastrin mRNA has been detected by PCR in many human colon cancers and colon cancer cell lines, suggesting that gastrin may be functioning as an autocrine growth factor in these tumor cells $(21,22,49)$. However, for a number of reasons, amidated forms of gastrin are not likely to play an autocrine role in colon cancer. First, no CCK-B or CCK-A receptor subtypes have been detected in normal or cancerous intestinal cells (19). In addition, at least two studies have shown that most colon carcinoma cell lines produce no detectable amidated gastrin but significant amounts of progastrin, which has little affinity for the CCK-B receptor $(25,26)$. Further, several studies have noted an increase in progastrin production in colorectal tumor tissue compared to normal mucosa, suggesting that progastrin may be functioning as an autocrine growth factor $(21,50-53)$. This autocrine growth factor theory has been supported by other experiments showing that proglumide can block the growth stimulation by gastrin of a number of xenografts $(54,55)$, as well as by studies demonstrating inhibitory effects of antigastrin antibodies on the growth of a human colon cancer cell line in vitro $(27,28)$. However, while a number of recent studies have examined the growth factor properties of glycine-extended gastrin in cell culture and shown growth stimulation $(18,19)$, few studies have looked directly at the growth effects of progastrin, in part because the length of the prohormone ( $>80$ amino acid residues) has precluded organic synthesis.

Our data presented here indicate that progastrin and amidated gastrin have equivalent growth effects on normal colonic mucosa, and thus are consistent with recent studies suggesting the existence of an additional receptor (CCK-C) receptor for gastrin which recognizes $\mathrm{COOH}$-terminally extend forms of gastrin and is expressed by normal colonic cells and colon cancer cells. Recently, several candidate receptors have been identified that appear to recognize gastrin processing intermediates. Seva and co-workers described a receptor for glycineextended gastrin 2-17 on the surface of the rat pancreatic carcinoma cell line AR4-2J (18). Another group reported a 45-kD gastrin preferring receptor on Swiss 3T3 cells that does not discriminate between amidated and glycine extended gastrin and apparently mediates mitogenic effects of gastrin-like peptides on these cells (19). Finally, Baldwin reported a 78-kD gastrin binding protein (GBP), purified from extracts of porcine gastric mucosal membrances, which binds glycine-extended forms of gastrin with similar affinity to mature amidated gastrin (20, 56). At present, it is unclear which, if any, of the above candidate receptors may be the colonic receptor mediating the growth effects of progastrin.

In summary, our study has provided the first permanent transgenic mouse model of human progastrin and amidated gastrin overexpression. Our results support a growth factor role for progastrin, implying the existence of an additional (non-A, non-B) CCK/gastrin receptor in the colon that does not require an amidated $\mathrm{COOH}$-terminal. Finally, our finding of increased colonic proliferation in hypergastrinemic mice adds further weight to preliminary reports suggesting that high gastrin levels may be associated with an increased risk of colorectal carcinoma (57).

\section{Acknowledgments}

This research was supported by research grants from the National Institute for Health (NIH) (RoI DK-48077) and the American Diabetes Association to T.C. Wang, and from the Medical Research Council and Wellcome Trust to A. Varro and G.J. Dockray. T.J. Koh was supported by a training grant from the NIH and by the AGA Senior Fellow Research Award. Oligonucleotides were provided by the Center for Studies of Inflammatory Bowel Disease, Massachusetts General Hospital, Boston.

\section{References}

1. Walsh, J.H., and M.I. Grossman. 1975. Medical progress: gastrin. N. Engl. J. Med. 292:1324-1377.

2. Walsh, J.H. 1988. Peptides as regulators of gastric acid secretion. Annu. Rev. Physiol. 50:41-63.

3. Larsson, L.I., J.F. Rehfeld, F. Sundler, and R. Hakanson. 1976. Pancre- 
atic gastrin in foetal and neonatal rats. Nature (Lond.). 262:609-610.

4. Brand, S.J., B.N. Andersen, and J.F. Rehfeld. 1984. Complete tyrosineO-sulphation of gastrin in neonatal rat pancreas. Nature (Lond.). 309:456-458.

5. Brand, S.J., and P.J. Fuller. 1988. Differential gastrin gene expression in rat gastrointestinal tract and pancreas during neonatal development. J. Biol. Chem. 263:5341-5347.

6. Wang, T.C., S. Bonner-Weir, P.S. Oates, M.B. Chulak, B. Simon, G.T. Merlino, E.V. Schmidt, and S.J. Brand. 1993. Pancreatic gastrin stimulates islet differentiation of transforming growth factor $\alpha$-induced ductular precursor cells. J. Clin. Invest. 92:1349-1356.

7. Wang, T.C., and S.J. Brand. 1990. Islet cell-specific regulatory domain in the gastrin promoter contains adjacent positive and negative DNA elements. $J$. Biol. Chem. 265:8908-8914.

8. Tillotson, L.G., T.C. Wang, and S.J. Brand. 1994. Activation of gastrin transcription in pancreatic insulinoma cells by a CACC promoter element and a 70-kDa sequence specific DNA-binding protein. J. Biol. Chem. 269:2234-2240.

9. Chung, D.C., S.J. Brand, and L.G. Tillotson. 1995. Mutually exclusive interactions between factors binding to adjacent Sp1 and AT-rich elements regulate gastrin gene transcription in insulinoma cells. J. Biol. Chem. 270:8829-8836.

10. Desmond, H., G. Pauwels, A. Varro, H. Gregory, J. Young, and G.J. Dockray. 1987. Isolation and characterization of the intact gastrin precursors from a gastrinoma. FEBS Lett. 210:185-188.

11. Dockray, G.J., and A. Varro. 1993. Post-translational processing. In Gastrin. J.H. Walsh, editor. Raven Press, Ltd., New York. pp. 33-46.

12. Varro, A., A. Voronina, and G.J. Dockray. 1995. Pathways of processing of the gastrin precursor in rat antral mucosa. J. Clin. Invest. 95:1642-1649.

13. Marino, L.R., T. Takeuchi, C.J. Dickinson, and T. Yamada, T. 1991. Expression and post-translational processing of gastrin in heterologous endocrine cells. J. Biol. Chem. 26:6133-6136.

14. Daugherty, D.F., C.J. Dickinson, T. Takeuchi, D. Bachwich, and T. Yamada. 1991. Expression and processing of human preprogastrin in murine medullary thyroid carcinoma cells. Am. J. Physiol. 260 (Gastrointest. Liver Physiol. 23):G783-G788.

15. Dickinson, C.J., D. Daugherty, Y.-J. Guo, P. Hughes, and T. Yamada. 1992. Molecular analysis of dibasic endoproteolytic cleavage signals. J. Biol. Chem. 267:21795-21801.

16. Dickinson, C.J., T. Takeuchi, Y.-J. Guo, B.T. Stadler, and T. Yamada. 1993. Expression and processing of prohormones in nonendocrine cells. Am. J. Physiol. 264 (Gastrointest. Liver Physiol. 27):G553-G560.

17. Dickinson, C.J., D. Daugherty, Y.-J. Guo, B. Stadler, S. Finniss, and T. Yamada. 1993. Substrate specificity of the gastrin amidating enzyme. J. Biol. Chem. 268:15929-15934.

18. Seva, C., C.J. Dickinson, and T. Yamada. 1994. Growth promoting effects of glycine-extended progastrin. Science (Wash. DC). 265:410-412.

19. Singh, P., A. Owlia, R. Espeijo, and B. Dai. 1995. Novel gastrin receptor mediates mitogenic effects of gastrin and processing intermediates of gastrin in Swiss 3T3 fibroblasts. J. Biol. Chem. 270:8429-8438.

20. Baldwin, G.S. 1995. Binding of progastrin fragments to the $78 \mathrm{kDa}$ gastrin binding protein. FEBS Lett. 359:97-100.

21. Rehfeld, J.F., and W.W. Van Solinge. 1994. Tumor biology of gastrin and cholecystokinin. Adv. Cancer Res. 63:295-347.

22. Jensen, S., K. Borch, L. Hilsted, and J.F. Rehfeld. 1989. Progastrin processing during antral G-cell hypersecretion in humans. Gastroenterology. 96: $1063-1070$

23. Nemeth, J., A. Varro, J. Bridson, R. Walker, and G.J. Dockray. 1992. Increased tissue concentrations of the gastrin precursor in patients treated with omeprazole. Eur. J. Clin. Invest. 22:638-644.

24. Rehfeld, J.F., and L. Hilsted. 1992. Gastrin and cancer. In Advances in Clinical Chemistry, H.E. Spiegel, editor. Academic, San Diego. 29:239-262.

25. Van Solinge, W.W., F.C. Nielsen, L. Friis-Hansen, U.G. Falkmer, and J.F. Rehfeld. 1993. Expression but incomplete maturation of progastrin in colorectal carcinomas. Gastroenterology. 104:1099-1107.

26. Singh, P., Z. Xu, B. Dai, S. Rajaraman, N. Rubin, and B. Dhruva. 1994. Incomplete processing of progastrin expression by human colon cancer cells: role of noncarboxyamidated gastrins. Am. J. Physiol. 266 (Gastrointest. Liver Physiol. 29):G459-G468.

27. Hoosein, N.M., P.A. Kiener, R.C. Curry, L.C. Rovati, D.K. McGilbra, and M.G. Brattain. 1988. Antiproliferative effects of gastrin receptor antagonists and antibodies to gastrin in human colon carcinoma cell lines. Cancer Res. 48:7179-7183.

28. Hoosein, N.M., P.A. Kiener, R.C. Curry, and M.G. Brattain. 1990. Evidence for autocrine growth stimulation of cultured colon tumor cells by a gastrin/cholecystokinin-like peptide. Exp. Cell. Res. 186:15-21.

29. Wiborg, O., L. Berglund, E. Boel, F. Norris, K. Norris, J.F. Rehfeld, K.A. Marcker, and J. Vuust. 1984. Structure of a human gastrin gene. Proc. Natl. Acad. Sci. USA. 81:1067-1069.

30. Ito, R., K. Sato, T. Helmer, G. Jay, and K. Agarwal. 1984. Structure analysis of the gene encoding human gastrin: the large intron contains an Alu sequence. Proc. Natl. Acad. Sci. USA. 81:4662-4666.

31. Low, M.J., R.M. Lechan, R. E. Hammer, R.L. Brinster, J.F. Habener, G. Mandel, and R.H. Goodman. 1986. Gonadotroph-specific expression of metallothionein fusion genes in pituitaries of transgenic mice. Science (Wash. DC).
231:1002-1004.

32. Borrelli, E., R.A. Heyman, C. Arias, P.E. Sawchenko, and R.M. Evans 1989. Transgenic mice with inducible dwarfism. Nature (Lond.). 339:538-541.

33. Cathala, G., J.F. Savouret, and J.D. Baxter. 1983. A method for isolation of intact translational active ribonucleic acid. DNA (NY). 2:324-335.

34. Schmidt, E.V., G. Christoph, R. Zeller, and P. Leder. 1990. The cytomegalovirus enhancer: a pan-active control element in transgenic mice. Mol. Cell. Biol. 10:4406-4411.

35. Wang, T.C., M.W. Babyatsky, P.S. Oates, Z. Zhang, L.G. Tillotson, M.B. Chulak, S.J. Brand, and E.V. Schmidt. 1995. A rat gastrin-human gastrin chimeric transgene directs antral $\mathrm{G}$ cell-specific expression in transgenic mice. Am. J. Physiol. 268 (Gastrointest. Liver Physiol. 31):G1025-G1036.

36. Varro, A., J. Henry, C. Vaillant, and G.J. Dockray. 1994. Discrimination between temperature- and brefeldin A-sensitive steps in the sulfation, phosphorylation, and cleavage of progastrin and its derivatives. J. Biol. Chem. 269: 20764-20770.

37. Montag, A.G., T. Oka, K.H. Baek, C.S. Choi, G. Jay, and K. Agarwal. 1993. Tumors in hepatobiliary tract and pancreas islets tissues of transgenic mice harboring gastrin simian virus 40 large tumor antigen fusion genes. Proc. Natl. Acad. Sci. USA. 90:6696-6700.

38. Pictet, R.L., and W.J. Rutter. 1972. Development of the embryonic endocrine pancreas. In Endocrinology. R.O. Greep and W.B. Astwood, editors Handbook of Physiology, American Physiological Society, Washington, DC $25-66$.

39. Scarpelli, D.G., and M.S. Rao. 1981. Differentiation of regenerating pancreatic cells into hepatocyte-like cells. Proc. Natl. Acad. Sci. USA. 78:25772581.

40. Rao, M.S., R.S. Dwivedi, A.V. Yeldandi, V. Subbarao, T. Xiaodi, M.I Usman, S. Thangada, M.R. Nemali, S. Kumar, D.G. Scarpeli et al. 1989. Role of periductal and ductular epithelial cells of the adult rat pancreas in pancreatic hepatocyte-lineage. A change in differentiation commitment. Am. J. Pathol 134:1069-1086.

41. Terada, T., and Y. Nakanuma, Y. 1995. Expression of pancreatic enzymes ( $\alpha$-amylase, trypsinogen and lipase) during human liver development and maturation. Gastroenterology. 108:1236-1245.

42. Walsh, J.H. Gastrin. 1994. In Gut Peptide Biochemistry and Physiology,

J.H. Walsh and G.J. Dockray, editors. Raven Press, Ltd., New York. 75-122.

43. Rehfeld, J.F. 1988. The expression of progastrin, procholecytokinin and their hormone products in pituitary cells. J. Mol. Endocrinol. 1:87-94.

44. Pauwels, S., H. Desmond, R. Dimaline, and G.J. Dockray. 1980. Identification of progastrin in gastrinomas, antrum, and duodenum by a novel radioimmunoassay. J. Clin. Invest. 77:376-381.

45. Ekman, L., E. Hansson, N. Havu, E. Carlsson, and C. Lundberg. 1985. Toxicological studies on omeprazole. Scand. J. Gastroenterol. 20 (Suppl. 108): 53-69.

46. Lee, Y.-M., M. Beinborn, E.W. McBride, M. Lu, L.F. Kolakowski, and A.W. Kopin. 1993. The human brain cholecystokinin-B/gastrin receptor. $J$. Biol. Chem. 268:8164-8169.

47. Johnson, L.R. 1976. The trophic action of gastrointestinal hormones. Gastroenterology. 70:278-288.

48. Singh, P., C.M. Townsend, Jr., J.C. Thompson, S. Narayan, and Y.-S Guo. 1990. Hormones in colon cancer: past and prospective studies. Cancer J. 3: 28-33.

49. Baldwin, G.S., and Q.-X. Zhang. 1992. Measurement of gastrin and transforming growth factor $\alpha$ messenger mRNA levels in colonic carcinoma cell lines by a quantitative polymerase chain reaction. Cancer Res. 52:2261-2267.

50. Finley, G.G., R.A. Koski, M.F. Melhem, J.M. Pipas, and A.I. Meisler. 1993. Expression of gastrin gene in the normal human colon and colorectal adenocarcinoma. Cancer Res. 53:2919-2926.

51. Kochman, M.L., J. DelValle, C.J. Dickinson, and C.R. Boland. 1992. Post-translational processing of gastrin in neoplastic human colonic tissues. Biochem. Biophys. Res. Commun. 189:1165-1169.

52. Nemeth, J., B. Taylor, S. Pauwels, A. Varro, and G.J. Dockray. 1992. Identification of progastrin derived peptides in colorectal carcinoma extracts. Gut. 34:90-105.

53. Ciccotosto, G.D., A. McLeish, K.J. Hardy, and A. Shulkes. 1995. Expression, processing, and secretion of gastrin in patients with colorectal carcinoma. Gastroenterology. 109:1142-1153.

54. Singh, P., S. Le, R.D. Beauchamp, C.M. Townsend, Jr., and J.C. Thompson. 1987. Inhibition of pentagastrin-stimulated up-regulation of gastrin receptors and growth of mouse colon tumor in vivo by proglumide, a gastrin receptor antagonist. Cancer Res. 47:5000-5004.

55. Beauchamp, R.D., C.M. Townsend, Jr., P. Singh, E.J. Glass, and J.C. Thompson. 1985. Proglumide, a gastrin receptor antagonist, inhibits growth of colon cancer and enhances survival in mice. Ann. Surg. 202:303-309.

56. Baldwin, G.S. 1994. Antiproliferative gastrin/cholecystokinin receptor antagonists target the 78-kDa gastrin-binding protein. Proc. Natl. Acad. Sci. USA. 91:7593-7597.

57. Thorburn, C.M., G.D. Friedman, N. Orentreich, J. H. Vogelman, and J. Parsonnet. 1996. High gastrin levels increase risk for colorectal carcinoma. Gastroenterology. 110:A603. 